\title{
Industrialization and Urbanization in Turkey at the beginning of the 20th Century
}

\author{
* Dr. Senem Zeybekoglu Sadri \\ Associate Professor, Department of Architecture, Girne American University, Northern Cyprus \\ E mail: senemsadri@gau.edu.tr
}

\section{ART I CLE I N F O:}

Article history:

Received 10 October 2019

Accepted 15 December 2019

Available online 15 January

2020

Keywords:

Industrialization;

Turkey;

Republican Era;

Architectural History.

This work is licensed under a Creative Commons Attribution

NonCommercial - NoDerivs 4.0. "CC-BY-NC-ND"

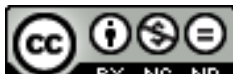

This article is published with Open Access at www.ijcua.com

\begin{abstract}
A B S T R A C T
The starting point of this study is the fact that every production system entails a specific spatial organization and changes its physical environment. This research is an attempt to understand the industrialization period of Turkey's Early Republican Period (1930's) and the spatial effects of the new production system. Right after the Turkish War of Independence, The Republican Government of Turkey had aimed to establish an independent country and started to carry out a modernization and contemporization project. This project had different dimensions appealing to the institutional, economical, social and civic aspects of Turkey. The economical dimension included the industrialization and economical independence of Turkey. Besides its economical, political and social goals, the Republican Government had aimed to change the physical appearance of the country. The Government's first goal was to turn the country into the space of the National Turkish Republic State from an empire's land. Secondly, the small towns or settlements of the country we're supposed to become modern cities, the places of modernity, just like the modern cities of the industrial and developed countries of the world. That explains why the factories which were set up all around the country had played such a crucial role in the modernization period of Turkey at the beginning of the Republican era. They were not only economic achievements of the state; they also affected their physical and social environments and introduced the modern way of living particularly where they were set up.
\end{abstract}

JOURNAL OF CONTEMPORARY URBAN AFFAIRS (2020), 4(2), 87-94.

https://doi.org/10.25034/ijcua.2020.v4n2-8

www.ijcua.com

Copyright (C) 2020 Journal of Contemporary Urban Affairs. All rights reserved.

\section{The Industrial Revolution}

The dynamics of the industrialization process of Turkey differed from those of the Industrial Revolution of European Countries. The economic, political and social structure of the Ottoman Empire did not allow such kind of industrialization. In the 18th century, Great Britain was subject to rapid economic development and urban population growth. The invention of machinery sealed the fate of the cottage industry and concentrated industry in factories. These factories, which were sited near water and coal deposits, encouraged migration from the agricultural settlements so that new urban developments mushroomed (Curl, 1970) 
After the Enclosure Acts and the deprivation of the yeomen of their ancient rights, the class differences were accentuated, wealth being concentrated in fewer hands, and the free men and their families became the proletariat, forming the labour factor of production. Rural depopulation was caused by several factors, but one which is often overlooked was the fact that the urban slums were probably a lot better than the rural ones (Curl, 1970).

\section{The Social and Economic Structure of the Ottoman Empire}

During the 18th century, the Ottoman Empire had appeared to carry the characteristics of a pre-industrial economy; poverty, stagnation, dependence on agriculture, lack of occupational specialization and the low degree of geographical integration (Curl, 1970). The reasons for this situation were the economic and social structure of the Ottoman Empire. Firstly, the majority of the population was formed of villagers, called as "reaya". They worked on the lands of the empire and paid taxes, and they did not constitute a class system. Secondly, the priority of the land was belonging to Sultan, and the local authorities (timar owners) of these lands were only responsible to collect the taxes from the real. They did not have the right to own land because the Ottoman's land policies did not allow any Enclosure Acts within the Empire. The whole system of the government was established on the gathering of surplus by the government from the reaya, so that any event that could cause accumulation of capital was prevented by the government

(Kongar, 1998).

The economic development of the European countries also affected the Ottoman's economical system. Firstly, the new trade ways eliminated the Mediterranean trade ways, thus the Ottoman Empire lost an important source of taxes it gathered from the control of these trade ways. Secondly, the metals like gold and silver which introduced into the European economy from the New World had caused inflation and increased the prices. Ottoman Empire turned into a cheap source of food and raw material. The Ottoman Empire had a stagnant economic and social system which obstructed the flow of money throughout the country. The low population rate, the production which depended on agriculture or crafts and its local connectedness, and the insufficiency of transportation and communication systems did not allow the labour to transfer from agricultural production to the activities concerned with industrial production. As a result, the rural population had no chance to move into urban communities. On the other hand, there was no demand for manufactures or services from the society, because of the poverty and low population, thus there had never been a demand for a big capacity of industrial production. The only places which were integrated with the world's market system were the harbour cities or the settlements which were set up on the trade ways of the caravans. But the hinterland of the Ottoman Empire could not integrate with this system. The delay of technological developments and education in the country made it obligatory to transfer specialists from European countries, and there was a lack of occupational specialization. Besides these reasons, the social status of the workers was always humiliated within the paternalist structure of the guild system and being a soldier or an official for the government had always been preferred to being an industrial worker by the society members (Belge \& Aral, 1985).

Table 1. The number of factories and workers according to the statistics of 1913-1915.

\begin{tabular}{|l|l|l|l|l|}
\hline & \multicolumn{2}{|l|}{$\begin{array}{l}\text { Number of } \\
\text { Factories }\end{array}$} & \multicolumn{2}{l|}{$\begin{array}{l}\text { Number } \\
\text { Workers }\end{array}$} \\
\hline $\begin{array}{l}\text { The Production } \\
\text { of the factory }\end{array}$ & 1913 & 1915 & 1913 & 1915 \\
\hline 1. Food & 76 & 78 & 4281 & 3916 \\
\hline 2. Earth & 20 & 21 & 980 & 336 \\
\hline 3. Leather & 12 & 13 & 930 & 1270 \\
\hline 4. Wood & 19 & 24 & 705 & 377 \\
\hline 5. Weaving & 75 & 78 & 7765 & 6763 \\
\hline 6. Paper & 55 & 55 & 1897 & 1267 \\
\hline 7. Chemistry & 12 & 13 & 417 & 131 \\
\hline
\end{tabular}

\section{The Industrialization Process of the Turkish Republic}

At the beginning of the Republican Era of Turkey (1920's), most of the consumer goods were imported from other countries. The world's Financial Crisis at the beginning of the 1930's affected Turkey's economy as well. The effects of the crisis on Turkey's economy were the deterioration of international terms of trade, the decrease of exportation and the decrease of government's budgetary incomes. The most important source of income of the Turkish economy, agricultural exportation, was becoming less profitable during this period, and the idea of industrialization was becoming more charming each day (Tezel, 1994).

The new Republican Government had aimed to develop the country and provide its economic independence by introducing contemporary industrial production. Thus, the private sector had been granted many privileges to realize the 
industrialization process of Turkey, but due to lack of enough experiment and capital, and the untrustworthy situation of the economic crisis of the day, the private sector could not handle this project (ÖZer, 2004).

At the beginning of the 1930s, the government decided to undertake the economical course of Turkey, by introducing many legislations and new applications. This was also one of the results of the state ruling policy of the government. One of the most important applications of this period was "The First Five Year Industrialization Plan" of Turkey, which had been prepared during 1932 and put into practice in 1934(Inan, 1972).

To find technical and financial support for the government's new economic policies, the Prime Minister İsmet Pascha (İnönü) visited many countries like the Soviet Union and Italy, in 1932. In the same year, a group of Soviet technicians came to Turkey to make surveys about the investigation programme of the Turkish government and at the end of the year, the group presented a report to the government.

But the government was not contented with this report and in 1933, a group of American specialists, in which the famous American economist Edwin Kemmerer had participated, was invited to Turkey. These specialists prepared a detailed report on Turkey's economic conditions, natural sources, capital resources, industry, transportation system, national and international trade system, money and banking system, foundations, working conditions, health and education system, and public administration. They presented their report to the Ministry of Economy in 1934. These researches forecasted that it could be possible to set up factories in Turkey more profitable than other countries of the world (Tezel, 1994).

These reports of Soviet and American Specialists determined the contents and form of the investment programme of the Turkish government. Most of the projects were supposed to be realized with the financial support of the Soviet Union.

However, the priorities of governmental capitalism were different from those of the realities of capitalist thinking during the realization of this plan. Instead of assembling at certain points of the country, the factories were dispersed throughout the country (Kessler, 1949). According to the plan, many factories producing consumer's goods were set up among Turkey's many different regions.
Table 2. The factories and their regions, (Tayanç, 1973)

\begin{tabular}{|c|c|}
\hline Region & $\begin{array}{l}\text { The production of the } \\
\text { factory }\end{array}$ \\
\hline $\begin{array}{l}\text { 1. Marmara Region } \\
\text { İstanbul } \\
\text { İzmit } \\
\text { Gemlik } \\
\text { d. Bursa }\end{array}$ & $\begin{array}{c}\text { cotton, glass } \\
\text { paper, cellulose, } \\
\text { phosphate, sulphur } \\
\text { artificial silk } \\
\text { merino wool }\end{array}$ \\
\hline $\begin{array}{l}\text { 2. Agean Region } \\
\text { Kütahya } \\
\text { Nazilli } \\
\text { c. Bodrum } \\
\end{array}$ & $\begin{array}{l}\text { ceramics } \\
\text { cotton } \\
\text { sponge }\end{array}$ \\
\hline $\begin{array}{l}\text { 3. Mediterranean Region } \\
\text { Keçiborlu } \\
\text { Isparta }\end{array}$ & $\begin{array}{l}\text { sulphur } \\
\text { oil of rose }\end{array}$ \\
\hline $\begin{array}{l}\text { 4. Black Sea Region } \\
\text { Kastamonu } \\
\text { Karabük }\end{array}$ & $\begin{array}{c}\text { hemp } \\
\text { iron-steel }\end{array}$ \\
\hline $\begin{array}{l}\text { 5. Middle Anatolia Region } \\
\text { Ereğli } \\
\text { Kayseri }\end{array}$ & $\begin{array}{l}\text { cotton } \\
\text { cotton }\end{array}$ \\
\hline $\begin{array}{c}\text { 6. Eastern Anatolia Region } \\
\text { Malatya } \\
\text { Iğdır }\end{array}$ & $\begin{array}{l}\text { cotton } \\
\text { cotton }\end{array}$ \\
\hline
\end{tabular}

This Industrialization plan was not only an economical plan but also put into practice the spatial strategies of the modernization project of the Republican Government (Tekeli, 1998). The places for the factories were chosen among the small cities or towns of Turkey which laid on the railway system so that even the smallest settlement could take the advantage of the factory and its services. The factories yielded employment, increase in population, industrialization and as a result urbanization of the small towns-settlements where they had been set up.

These factories resembled the company towns of Europe and America which firstly occurred in the 19th century. A company town was a community inhabited by the employees of a single company or groups of companies that also own a substantial part of the real estate and houses (Crawford, 1995). These company towns were the challenges of the paternalist investors against the intolerable conditions of living and the new values system of the new industrial era.

Pullman in the United States of America is a good example for the company towns. It was a healthy and rational environment with its well-organized plan. It was not only an industrial complex, but also it was offering a new way of life with its accident insurance, a company doctor, a school system, athletic clubs, a company band, social and educational clubs for workers.

Saltaire in Yorkshire (1860) was another important company town, with its district social rules and clear landscape planning. The factory building and the church are just opposite of each other. On the main axial road of the settlement lies the 
factory schools, club and institute buildings. Behind these buildings, there are the workers' houses (Kostof, 1991).

In Turkey, the factories, the new production system, but their effects on the economic and social structure of the community, and also on the physical environment. Firstly, the people who used to earn their livings by agriculture or crafts began to learn how to work in a factory system, from turning the machines on, to come to work on time, or from living in mass houses of the factory to negotiating for their salaries. They began to be the members of a working-class, not only a family or a tribe. The workers coming from the rural areas of Anatolia to the settlements where the factories were set up caused an increase in population and that was the first and a very important step for urbanization. The increase of population necessitated new houses, new services and new recreational facilities all through the settlement. Industrial production also revitalized the economic structure with its demand for raw material and small industrial production. Secondly, the factory complexes, with their grid layout plans, housing units for workers, social services, infrastructures and recreational areas, introduced a new kind of building type into the small and rural settlements of Anatolia. These services of the factory also affected the urbanization process of the settlements.

These complexes were not only the spaces of production, but also they served as the cultural centres and gathering places for the community. As women started to work at the factories, they became active members of social life. The social activities organized by the factories (among these the celebration parties of the national ceremonies, sports activities, theatre performances, reading and writing courses for non-readers can be listed) played an effective role in the education of people. The people living in the town were able to use the green areas of the factory for recreational activities. By that means, the factory complex served also as a public space where people could meet with each other, educate, recreate, and took the advantage of many services. Those were the first steps of a community towards a modern way of life through the factories, which introduced them to the industrial production system.

Here two of these factories are compared with each other according to their spatial properties. One of them is the "Sümerbank Nazilli Basma (printed cotton cloth) Factory", which was set up between the years 1935-937. This factory was a very important step of the First Five Year Industrialization Plan, as it was one of the first factories that were realized and began production. The plans of the factory were drawn by a Soviet firm "Turkstroj", and during the building of the factory, engineers from the Soviet Union worked in Turkey, both to build the factory and to educate Turkish engineers and workers. Another factory is "Sümerbank Kayseri Weaving Factory" which was opened in 1935. Kayseri factory was also set up with the technical and financial support of the Soviet Union (Inan, 1972). The plans of the two factory buildings are very similar to each other.

When we take a look at the layout plans of the factories, we observe a rational grid system and very huge buildings which oppose the organic and traditional layout of the small towns. This is because an industrial landscape is a direct

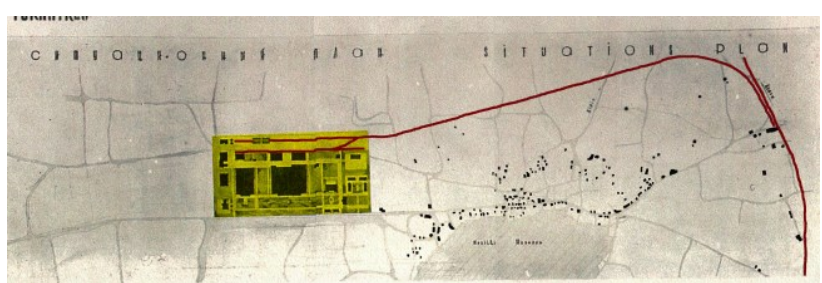

Figure 1. The Sümerbank Nazilli Basma Factory 1934, the original plan drawing, Factory Library.

translation of the technical and social necessities of a particular method of industrial production into a settlement form(Crawford, 1995). The factories are connected to the main railway system with a narrow-gauge railway where possible. This maintained the transportation of raw materials and the products of the factory, and also served to carry the workers to factories in some places.

Both of the factories are symmetrical in planning and a hierarchy is visible among the building groups. The production units of the factories are located at the centre of this hierarchy after they are the administration offices and the residential units of the administrative staff in the boundaries of the factory settlements. The workers' houses had been added by time in case of need, and they are located just opposite of the factory. The infrastructure of the factories like power station or water plumbing system served the whole town. Other services and facilities of the factories included health care centre, primary school, nursery centre, cinema, sports complex, library, fire station, and a restaurant which could be used as an assembly hall.

These two factory buildings were built with steel frame and concrete, which were the most contemporary building technologies of their era. The buildings are, simple and functionalist buildings, which reflect the modernist tendencies of the of 20th century's industrial production systems. When we take a look at the production units of the factories, we can even observe the 
effects of the Russian Constructivism on these buildings (the combination of rational elements in harmony to form a unity) (Issawi, 1980).

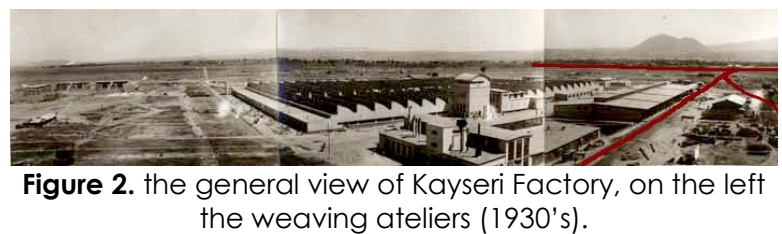

\section{Conclusion}

The Industrialization of Turkey in the Early Republican Period was an attempt to build up an economically independent and modern country. After the war of independence, the government had to undertake the economical course of Turkey, and the First Five Year Industrialization Plan was a successful application of the government during this period because all the projects that had been intended in this plan were realized, either with national or out coming budgets.

This industrialization process differed from the "Industrial Revolution" of European countries during the 18th and 19th centuries and had its own social and economical dynamics. Firstly, the economical activities of the Ottoman Empire were depended on agriculture and crafts and the only factories limited in number were produced for the army. Thus, the industrialization of the whole country was a new situation for the Republican government and the public. Secondly, the population was very low with the effects of wars and stabilized to rural settlements, and the beliefs and traditions of the community were not appropriate to form the immobile society which the industrial production system needed. The insufficiency of the transportation system was another reason for this. Thirdly, the factories were not private investments, they were the investments of government, so the industrialization process of Turkey could not be named as a public wide "revolution", it was only a governmental policy applied during a limited time and with limited resources.

In addition, there had been a sudden change in the governing of the country and parallel with the policies of the modern government, the factories changed the socio-economical structure of the society and affected the physical environment of the settlements where they had been set up. The increase of population and the development of the economic activities depending on the demands of the factory and production for and integrating with the world's market system caused the urbanization of these settlements. The cities took their shape according to these factories and new industrial sites and new neighbourhoods surrounded the factories. The social activities organized by the local authorities and the administrations of the factories gathered the public together and these were new kinds of activities for a previously agricultural community (including sports activities, theatre performances, cinemas, the celebrations of the public days, libraries, reading and writing courses).

But the success of this period could not be sustained long. Especially after the 1950s, the factories began to lose their effectiveness, and most of them are closed now. Luckily enough, the above-mentioned factories are now properties of two different state universities. The buildings and the land of "Nazilli Basma Factory" were purchased by Aydın Adnan Menderes University and there are some projects prepared by the municipality of Nazilli to turn these places into a techno-park. The Weaving Factory of Kayseri became the property of Erciyes University in Kayseri, and the university is planning to change some of the buildings of the factory into a campus for the university.

With the above-mentioned effects of the factories, it can be said that the government's spatial goals concerned with the towns and cities of Modern Turkey were realized particularly, where the factories were set up. The modernization process of these towns depended on industrialization and urbanization. Therefore, these factories exemplify spatial forms of new means of production, which in the last analysis changed the social aspects. In other words, these were the factories that produced "cities".

\section{Acknowledgement}

This research did not receive any specific grant from funding agencies in the public, commercial, or not-for-profit sectors.

\section{Conflict of interests}

The authors declare no conflict of interest.

\section{References}

Belge, M., \& Aral, F. (Eds.). (1985). Tanzimat'tan Cumhuriyet'e Türkiye ansiklopedisi [Reforms of the Republic of Turkey encyclopedia]. Communication Publications.

Crawford, M. (1995). Building the Workingman's Paradise: The Design of American Company Towns. Verso.

Curl, J. S. (1970). The European Cities and Society. Leonard Hill.

İnan, A. (1972). Devletçilik ilkesi ve Türkiye Cumhuriyetinin birinci sanayi planı 1933 [Statism principle of the first industrial plan and the Republic of Turkey 1993]. Turkish Historical Society. 
Issawi, C. P. (1980). The economic history of Turkey, 18001914. Chicago: University of Chicago Press.

Kessler, G. (1949). Zonguldak ve Karabük’teki Çalışma Şartları [Working Conditions in Zonguldak and Karabük]. Ankara University Journal of Faculty of Economy, 7-33. https://dergipark.org.tr/en/download/articlefile/9678

Kongar, E. (1998). Yüzyllda Türkiye [Century in Turkey] Remzi Kitabevi.

Kostof, S. (1991). The city shaped: urban patterns and meanings through history. Thames and Hudson.
ÖZer, D. D. M.. (2004). Türkiye Ekonomisi [Turkish economy]. Anatolian University.

Tayanç, T. (1973). Sanayileşme sürecinde 50 yıl [50 years in the industrialization process]. Milliyet Publications.

Tekeli, İ. (1998). Bir Modernleşme Projesi Olarak Türkiye'de Kent Planlamasi [As a Modernlas Project Urban Planning in Turkey].

Tezel, Y. S. (1994). Cumhuriyet döneminin iktisadi tarihi, 1923-1950 [Economic history of the Republican era, 1923-1950]. History Foundation Yurt Publishing.

Check for

Updates

How to Cite this Article:

Zeybekoglu Sadri, S. (2020). Industrialization and Urbanization in Turkey at the beginning of the 20th Century. Journal of Contemporary Urban Affairs, 4(2), 87-94. https://doi.org/10.25034/ijcua.2020.v4n2-8 